\title{
Superimposition of Sulphur and Boron on Production and Quality of Chickpea (Cicer arietirum L.)
}

\author{
V.K. Verma*, Jitendra Yadav, Ram Pyare, U.S. Tiwari and Mithlesh Verma \\ Department of Agronomy, CSAUA\&T, Kanpur, India \\ *Corresponding author
}

\section{Keywords}

Boron, Chickpea,

NPK doses,

Superimposition

effect, Sulphur

Article Info

Accepted:

15 February 2019

Available Online:

10 March 2019

\section{A B S T R A C T}

The present study was conducted during the Rabi seasons of 2014-15 and 2015-16 at SIF Farm of Chandra Shekhar Azad University of Agriculture \& Technology, Kanpur, Uttar Pradesh, India to find out suitable superimposed nutritional doses for increase in production, productivity and economics of chickpea in Central Plain Zone. The treatments consisted seven (7) superimposed doses of sulphur $\left(25 \mathrm{~kg} \mathrm{ha}^{-1}\right)$, Boron $\left(1.0 \mathrm{~kg} \mathrm{ha}^{-1}\right), \mathrm{FYM}$ $\left(5.0 \mathrm{t} \mathrm{ha}^{-1}\right)$ used a individually, Rhizobium culture + FYM, Sulphur+ Boron, Sulphur + Boron + FYM, Sulphur + Boron + FYM + Rhizobium in combination along with NPK $\left(20: 60: 20 \mathrm{~kg} \mathrm{ha}^{-1}\right)$ doses compared with only NPK $\left(20: 60: 20 \mathrm{~kg} \mathrm{ha}^{-1}\right)$ dose (control treatment). The experiments were laid out in Randomized Block Design, replicated three times. The response of above treatments is analyzed on growth parameters, yield attributes and yield as well as quality of chickpea, variety KWR-108. The superimposition effect of sulphur, Boron, FYM and Rhizobium species along with NPK doses in different treatment exhibited significant response is terms of increasing grain yield to the tune of 23 percent to 62 percent compared to control treatment. Among different treatments superimposed doses of NPK (20:60:20 kg ha $\left.{ }^{-1}\right)+$ Sulphur $\left(25 \mathrm{~kg} \mathrm{ha}^{-1}\right)+$ Boron $\left(1.0 \mathrm{~kg} \mathrm{ha}^{-1}\right)+$ FYM $\left(5.0 \mathrm{t} \mathrm{ha}^{-1}\right)$ + Rhizobium inoculation treatment recorded maximum grain yield $\left(1348.14 \mathrm{~kg} \mathrm{ha}^{-1}\right.$ and $\left.1873.21 \mathrm{~kg} \mathrm{ha}^{-1}\right)$, Nitrogen content (3.34\% and 3.37\%), Phosphorus content $(1.46 \%$ and $1.47 \%)$, Potash content $(0.65 \%$ and $0.67 \%)$, Sulphur content $(0.61 \%$ and $0.63 \%)$ and Boron content (57 ppm and $58 \mathrm{ppm}$ ) in grain during 2014-15 and 2015-16, respectively compared to NPK only (control) treatment, which recorded lowest grain yield $(1000.73 \mathrm{~kg}$ $\mathrm{ha}^{-1}$ ) and $\left.1154.54 \mathrm{~kg} \mathrm{ha}^{-1}\right)$, Nitrogen content $(3.18 \%$ and $3.20 \%)$, Phosphorus content $(1.23 \%$ and $1.25 \%)$, Potash content $(0.47 \%$ and $0.49 \%)$, Sulphur content $(0.43 \%$ and $0.45 \%$ ) and Boron content (41 ppm and $42 \mathrm{ppm}$ ) in grain during 2014-15 and 2015-16, respectively.

\section{Introduction}

Pulses have been the main stay of the agriculture and nutrition of the people in the developing world especially for vegetarian.
Among the pulses chickpea (Cicer arietinum L.) is the third most important crop after drybean (Phasealus vulgaris L.) and dry peas (Pisum asativum L.) chickpea is an important source of energy, protein and soluble and 
insoluble fibre. Mature chickpea grains contain $60-65 \%$ carbohydrate, $6 \%$ fat and between $12 \%$ to $31 \%$ protein higher than any other pulse crop.

India rank $1^{\text {st }}$ in area $(71 \%)$ and production $(71.95 \%)$ in chickpea at global level followed by Pakistan, Iran and Australia but productivity is very low i.e. only $995 \mathrm{~kg} \mathrm{ha}^{-1}$. China rank $1^{\text {st }}$ in terms of productivity of 3759 $\mathrm{kg} \mathrm{ha}{ }^{-1}$ followed by Israel, Republic of Moldova and Bosnia \& Heizegovina (Anonymous, 2016-17).

The low productivity of chickpea is corelated with improper nutrition and moisture stress condition as well as heavy infestation of diseases and pest. Chickpea are usually grown under stored residual soil moisture with the moisture receding to deeper soil layers with the age of the plants experiencing terminal drought stress.

The intensity and timing of the stress, of course, can vary depending on rainfall, soil type, crop duration and crop growth. The deficiency major and micro nutrients have been very pronounced under multiple cropping system and hence their exogenous supplies an urgently required. Except that during one to two decades the practice of reducing inorganic fertilizer doses by 25 to $50 \%$ with complementary doses of organic manures did not achieved sustainability in crop production. The integration of super imposed quantity of micronutrients, organic manures, microbial supplements along with $100 \%$ dose of NPK catching attention of scientific communities, now days.

Thus keeping above facts in view the present investigation was formulated and conducted with the objective that assess impact of super imposed doses of nutrients on growth, yield and quality of chickpea in irrigated condition of Central Uttar Pradesh (India).

\section{Materials and Methods}

Field experiments were conducted during two consecutive rabi seasons of 2014-15 and 201516 at students' Instructional Farm of C.S. Azad University of Agriculture \& Technology, Kanpur, Uttar Pradesh, India situated at 125.9 meter altitude, 26.4148 north latitude and 80.2321 East longitude. Treatments involved in the study viz. NPK $(20: 60: 20 \mathrm{~kg} / \mathrm{ha})$ only (control), NPK + Sulphur (25 kgha $\left.{ }^{-1}\right)$, NPK + Boron $(1.0 \mathrm{~kg}$ $\left.\mathrm{ha}^{-1}\right), \mathrm{NPK}+$ Rhizobium (20.0 kg/ha seed), $\mathrm{NPK}+\mathrm{FYM}$ and $\mathrm{NPK}+\mathrm{S}+\mathrm{B}+\mathrm{FYM}+$ Rhizobium laid out in Randomized Block Design replicated three times. The variety KWR 108 (matures in 130-135 days) was used in study having ability to produce $18-20 \mathrm{q} / \mathrm{ha}$ yield. The soil of the experimental field was sandy loam with 54.30 per cent sand, $27.20 \%$ silt and $18.50 \%$ clay and $\mathrm{pH}$ of 7.92 . It was moderately fertile being low in carbon $(0.34 \%)$ available $\mathrm{N}$ (172 kg/ha), medium in available $\mathrm{P}_{2} \mathrm{O}_{5}(13.0 \mathrm{~kg} / \mathrm{ha})$ and available $\mathrm{K}_{2} \mathrm{O}$ (151.0 kg/ha).

The meterological observations recorded during the two seasons of study revealed that the maximum temperature averaged of $33.8^{\circ} \mathrm{C}$ and $15.65^{\circ} \mathrm{C}$ minimum at $16.45^{\circ} \mathrm{C}$ and $3.40^{\circ} \mathrm{C}$, relative humidity at $97 \%$ and $53.5 \%$ and cumulative rainfall at $212.0 \mathrm{~mm}$ and $49.3 \mathrm{~mm}$, respectively during the year 2014-15 and 2015-16. A higher rain fall of $71.5 \mathrm{~mm}$ and 95 $\mathrm{mm}$ in the $9^{\text {th }}$ SMW and $11^{\text {th }}$ SMW (26 Feb to 4 March and 12-18 march) during 2014-15 at flowering and fruiting stage affected badly to crop condition. It reduces crop productivity in the same year. Crop responses to the treatments were measured in terms of predetermined quantitative indices. The year wise observation so recorded was subjected to statistical analysis. Valid comparisons between various treatments were drawn using the respective C.D. (critical difference) values. 


\section{Results and Discussion}

\section{Growth characteristics (Table 1)}

Integration of major and micronutrients, organic manure and Rhizobium species depicted significant improvement in growth characters over individual application of major and micronutrients, FYM and Rhizobium inoculation. Combined application of NPK + sulphur + Boron + FYM + Rhizobium inoculation increased $15.91 \%$ plant height, $34.78 \%$ plant fresh weight, $15.19 \%$ plant dry weight, $55.13 \%$ nodules plant $^{-1}$ and $28.13 \%$ branches plant ${ }^{-1}$ during both years compared to NPK only treatment (control). The improvement in growth may be due to sulphur application because sulphur induced the process of photo synthesis and production of protein. It also pomotes the nodulation process in legumes. Boron promotes cell multiplication specially growing tips, xylem and phloem and enhances uptake of other nutrients and nutrient use efficiency (Prasad $e t$ al., 2014). Similar findings are reported by Dixit et al., (2014) and Desh Mukh et al., (2015).

\section{Yield attributes and yield}

The data representing yield attributes and yield are summarised in Table 2, exhibited that superimposition of sulphur, boron, FYM and Rhizobium culture significantly increase yield attributes and yield of chickpea. The increment in yield attributes recorded $17.32 \%$ pods plant ${ }^{-1}, 30 \% 28$ seeds pod $^{-1}$ and $21.79 \%$ 100 grain weight compared to NPK only treatment (control). The grain yield of Chickpea increased significantly to tune of $37.71 \%$ and $62.25 \%$ during $2014-15$ and 2015-16, respectively compared to only NPK treatment (control). The enhancement in yield attributes and yield of chickpea may be due to application of sulphur and boron along with FYM and Rhizobium culture. Sulphur promotes formation of seed and their yield because it is the constituent of nitrogenase, an enzyme involved in biological nitrogen fixation and nitrate reductase which calalyzes the synthesis of plant proteins. Boron promotes flowering, development of pollen tubes and germination and growth of pollen grains. FYM is well known to enhance nutrient use efficiency which ultimately increase the development of yield attributes and yield of crops (Prasad et al., 2015). The findings are coroborated with the findings of Islam et al., (2011), Dixit et al., (2014) and Shivram and Chandra (2012).

\section{Quality of chickpea}

The data regarding grain quality of chickpea are summarised in Table 3, exhibited significant response in increasing nitrogen, phosphorus, potash, sulphur and boron content in grain. Combined application of NPK + Sulphur+Boron+ FYM Rhizobium culture recorded significantly maximum improvement viz. $5.17 \%$ nitrogen, $18.14 \%$ phosphorus, $37.51 \%$ potash, $43.43 \%$ sulphur and $38.55 \%$ boron content in chickpea grain compared to NPK only (control) treatment.

The improvement in quality of grain is positively correlated with the application of sulphur and boron. Sulphur interacts positively with other nutrients (Boron and Nitrogen) and improves protein content in grain. Sulphur is the constituent of 3 inter-related sulphur bearing amino acids (cysteine, cystine and methionine) which helps in stabilizing protein structure.

Boron enhances flowering and fruiting of legumes crops. FYM is considered as resorvior of different nutrients which enrich grain quality of crops (Prasad et al., 2014). Similar findings are reported by Katiyar et al., (2015) and Das et al., (2016). 
Table.1 Growth characters of chickpea as influenced by major and minor nutrients, FYM and Rhizobium culture

\begin{tabular}{|c|c|c|c|c|c|c|c|c|c|c|}
\hline \multirow{2}{*}{ Treatments } & \multicolumn{2}{|c|}{ Plant height $(\mathrm{cm})$} & \multicolumn{2}{|c|}{ Plant fresh wt.(g) } & \multicolumn{2}{|c|}{ Plant dry wt. (g) } & \multicolumn{2}{|c|}{ Nodules/Plant } & \multicolumn{2}{|c|}{ Branches/Plant } \\
\hline & 2014-15 & 2015-16 & 2014-15 & 2015-16 & 2014-15 & 2015-16 & 2014-15 & 2015-16 & 2014-15 & 2015-16 \\
\hline NPK (20:60:20) & 41.60 & 43.45 & 25.07 & 31.25 & 21.05 & 29.65 & 22.33 & 21.00 & 24.16 & 27.62 \\
\hline NPK+Sulphur@25 kg ha ${ }^{-1}$ & 44.20 & 46.26 & 26.03 & 37.50 & 22.12 & 31.05 & 26.33 & 23.08 & 25.33 & 31.10 \\
\hline NPK + Boron@1.0 kg ha ${ }^{-1}$ & 44.70 & 46.71 & 27.74 & 33.66 & 23.68 & 27.97 & 26.33 & 24.75 & 25.75 & 32.16 \\
\hline$\underset{1}{\mathrm{NPK}}+$ Rhizbium + FYM @ 5 tha $^{-}$ & 44.60 & 46.75 & 27.62 & 35.66 & 22.36 & 30.16 & 30.33 & 33.08 & 25.82 & 32.97 \\
\hline NPK + FYM @ 5 tha $^{-1}$ & 43.70 & 46.16 & 29.78 & 36.25 & 21.80 & 31.04 & 27.33 & 28.50 & 24.83 & 34.04 \\
\hline $\mathrm{NPK}+\mathrm{S}+\mathrm{B}$ & 47.80 & 49.82 & 31.22 & 39.25 & 23.15 & 32.24 & 26.33 & 29.33 & 28.00 & 35.64 \\
\hline $\mathrm{NPK}+\mathrm{S}+\mathrm{B}+\mathrm{FYM}$ & 48.13 & 49.95 & 32.72 & 40.91 & 23.72 & 33.64 & 27.67 & 31.41 & 28.25 & 36.75 \\
\hline NPK + S + B+ FYM + Rhizobium & 48.67 & 50.10 & 34.56 & 41.16 & 24.54 & 33.75 & 31.00 & 36.08 & 29.42 & 37.15 \\
\hline $\mathrm{SE}(\mathrm{d}) \pm$ & 1.172 & 1.217 & 2.347 & 3.153 & 0.937 & 1.328 & 1.859 & 2.317 & 0.605 & 1.212 \\
\hline CD $(5 \%)$ & 2.538 & 2.604 & 5.034 & 6.763 & 2.009 & 2.848 & 3.987 & 4.969 & 1.297 & 2.593 \\
\hline
\end{tabular}

Table.2 Yield attributes and yield of chickpea as influenced by major and minor nutrients, FYM and Rhizobium culture

\begin{tabular}{|c|c|c|c|c|c|c|c|c|c|c|}
\hline \multirow[t]{2}{*}{ Treatments } & \multicolumn{2}{|c|}{ Pods/plants } & \multicolumn{2}{|c|}{ Seeds/Pod } & \multicolumn{2}{|c|}{100 grain wt. (g) } & \multicolumn{2}{|c|}{$\begin{array}{c}\text { Grain Yield (k } \\
\text { ha-1) }\end{array}$} & \multicolumn{2}{|c|}{$\begin{array}{c}\text { Straw Yield (kg } \\
\left.\text { ha }^{-1}\right)\end{array}$} \\
\hline & 2014-15 & 2015-16 & 2014-15 & 2015-16 & 2014-15 & 2015-16 & 2014-15 & 2015-16 & 2014-15 & 2015-16 \\
\hline NPK (20:6 & 35.00 & 47.52 & 1.52 & 1.25 & 16.94 & & 1000.73 & 1154.51 & 1057.67 & 1.41 \\
\hline NPK+Sulphur@25 kg ha ${ }^{-1}$ & 36.58 & & 1.61 & 1.41 & & & 1125.92 & 1425.82 & 1348.15 & 1423.71 \\
\hline NPK + Boron@1.0 kg ha ${ }^{-1}$ & 38.25 & 52.77 & 1.68 & 1.16 & 17.32 & 17.44 & 1146.65 & 1373.02 & 1230.04 & 1486.23 \\
\hline NPK + Rhizbium + FYM @ 5 th & 36.92 & 52.64 & 1.64 & 1.17 & 17.25 & 17.22 & 1100.61 & 1390.61 & 1273.10 & 1490.86 \\
\hline NPK + FYM @ 5 tha $^{-1}$ & 35.08 & 57.83 & 1.72 & 1.42 & 17.33 & 17.33 & 1056.29 & 1307.42 & 1423.05 & 1448.13 \\
\hline $\mathrm{NPK}+\mathrm{S}+\mathrm{B}$ & 38.33 & 55.08 & 1.77 & 1.25 & 17.54 & 19.22 & 1231.10 & 1621.21 & 1494.82 & 1556.24 \\
\hline $\mathrm{NPK}+\mathrm{S}+\mathrm{B}+\mathrm{FYM}$ & 40.00 & 57.58 & 1.89 & 1.42 & & & 1293.33 & 1701.51 & 1640.00 & 1728.15 \\
\hline $\mathrm{NPK}+\mathrm{S}+\mathrm{B}+\mathrm{FYN}$ & 41.25 & 55.50 & 1.93 & 1.67 & 19.39 & 21.37 & 1348.14 & 1873.21 & 1733.34 & 1780.45 \\
\hline $\mathrm{SE}(\mathrm{d}) \pm$ & 1.385 & & 0.106 & & & & & 85.70 & 87.86 & 89.41 \\
\hline CD (5\%) & 2.970 & 3.798 & 0.229 & 0.224 & 1.035 & 2.607 & 150.96 & 183.82 & 188.45 & 191.76 \\
\hline
\end{tabular}


Table.3 Quality of chickpea influenced by major and minor nutrients, FYM and Rhizobium culture

\begin{tabular}{|c|c|c|c|c|c|c|c|c|c|c|}
\hline \multirow[t]{2}{*}{ Treatments } & \multicolumn{2}{|c|}{ Nitrogen (\%) } & \multicolumn{2}{|c|}{ Phosphorous (\%) } & \multicolumn{2}{|c|}{ Potash $(\%)$} & \multicolumn{2}{|c|}{ Sulphur (\%) } & \multicolumn{2}{|c|}{ Boron (ppm) } \\
\hline & 2014-15 & 2015-16 & 2014-15 & 2015-16 & 2014-15 & 2015-16 & 2014-15 & 2015-16 & 2014-15 & 2015-16 \\
\hline NPK (20:60:20) & 3.18 & 3.20 & 1.23 & 1.25 & 0.47 & 0.49 & 0.43 & 0.45 & 41 & 42 \\
\hline NPK+Sulphur@25 kg ha ${ }^{-1}$ & 3.28 & 3.31 & 1.35 & 1.37 & 0.49 & 0.58 & 0.54 & 0.57 & 45 & 47 \\
\hline NPK + Boron@1.0 kg ha & 3.22 & 3.25 & 1.26 & 1.29 & 0.50 & 0.51 & 0.46 & 0.48 & 51 & 53 \\
\hline $\begin{array}{l}\text { NPK + Rhizbium + FYM @ } 5 \\
\text { tha }^{-1}\end{array}$ & 3.26 & 3.28 & 1.32 & 1.33 & 0.55 & 0.56 & 0.51 & 0.54 & 49 & 51 \\
\hline NPK + FYM @ 5 tha $^{-1}$ & 3.24 & 3.27 & 1.29 & 1.31 & 0.53 & 0.54 & 0.49 & 0.51 & 47 & 49 \\
\hline $\mathbf{N P K}+\mathbf{S}+\mathbf{B}$ & 3.30 & 3.33 & 1.39 & 1.41 & 0.59 & 0.61 & 0.56 & 0.59 & 53 & 54 \\
\hline $\mathrm{NPK}+\mathrm{S}+\mathrm{B}+\mathrm{FYM}$ & 3.32 & 3.34 & 1.42 & 1.45 & 0.62 & 0.65 & 0.59 & 0.61 & 55 & 57 \\
\hline NPK + S + B+ FYM + Rhizobium & 3.34 & 3.37 & 1.46 & 1.47 & 0.65 & 0.67 & 0.61 & 0.63 & 57 & 58 \\
\hline $\mathrm{SE}(\mathrm{d}) \pm$ & 0.02 & 0.01 & 0.009 & 0.009 & 0.004 & 0.005 & 0.003 & 0.004 & 0.75 & 0.78 \\
\hline CD $(5 \%)$ & 0.07 & 0.05 & 0.030 & 0.030 & 0.01 & 0.01 & 0.01 & 0.01 & 1.608 & 1.672 \\
\hline
\end{tabular}


Based on above findings of results it may be concluded that superimposition of Sulphur and Boron recorded improvement in growth characters, yield attributes, yield as well as quality of Chickpea in the present location.

\section{References}

Annonymous (2016-17), Annual Report, Directorate of Pulses Development, Ministry of Agriculture \& Farmers Welfare, New Delhi.

Das, Shrila; Aditya, Kaustav; Singh Man (2016). Evaluation of Rhizobium efficiency in Chickpea through Boron Management. Bhartiya Krishi Anusandhan Patrika 31(3): 181-186.

Deshmukh, K.K., Saraiya, A.B., Dubey, D.P. (2005). Effect of integrated nutrient management on productivity trends, economics and soil fertility in soybean chickpea cropping system. JNKVV Research Journal 39(2): 29-32.

Dixit, A.K., Sunil Kumar; Rai, A.K., Palsaniya, D.R. (2014). Productivity and profitability of fodder sorghum + cowpea - chickpea cropping system as influenced by organic manures, phosphorus and sulphur application in Central India. Range management and Agro-forestry 35(1): 66-72.

Gangawar, S. and Dubey, M. (2012). Effect of N. and P. uptake by Chickpea (Cicer arietinum L.) as influenced by micronutrient and biofertilizers. Legume Research 35(2): 164-168.

Guhey, Arti; Sha, R.A; Khan, M.I., Kuruwanshi, V.B. (2008). Effect of Boron application on germination, nodulation, Chlorophyll content flower drop \& seed yield in chickpea (Cicer arietinum L.). Advances in Plant
Sciences, 21: 333-335.

Gupta, S.C. and Shahu, Seema (2012). Response of chickpea of micronutrient and biofertilizers in vertisol. Legume Research - an International Journal, 35(3): 248-251.

Islam, Muhammad, Saleem, Mohsan Safdar; Ali Rizwan; Khalid Fayyaz-ul-Hassan and Abid. Mahmood Subhani (2011). Growth, nitrogen fixation and nutrient uptake by chickpea (Cicer arietinum L.) in response to phosphorus and sulphur application under rainfed condition in Pakista. International Journal of Agriculture and Biology 13(5): 725-730. Katiyar, N.K., Mishra, U.S. and Pathak, R.K. (2015). Influence of Zinc, Boron and Molybdenum Application on Biochemical Composition of Chickpea Grain Grown under Rainfed conditions of Madhya Pradesh. Indian Journal of Agricultural Biochemistry, 28(2):191193.

Murari, L. Mathur A.K. Purohit H.S., and Meena, R.H. and Solanki, R.L. (2013). Effect of phosphorus and sulphur on yield, quality and nutrient uptake by chickpea (Cicer arietinum L.). Environment and Ecology 31(1A): 325327.

Prasad R., Kumar, D., Rana, D.S., Shivay, Y.S. and Tewatia, R.K. (2014). Text Book of Plant Nutrition Management, pp-147148 \& 189, Indian Society of Agronomy, IARI, New Delhi 110012.

Shivram, R.K., Prakash Chandra (2012). Productivity, profitability and protein content of chickpea (Cicer arietinum L.) as influenced by FYM, Phosphorus and sulphur application. Trends in Bioscience 5(2): 104-106.

\section{How to cite this article:}

Verma, V.K., Jitendra Yadav, Ram Pyare, U.S. Tiwari and Mithlesh Verma. 2019. Superimposition of Sulphur and Boron on Production and Quality of Chickpea (Cicer arietirum L.). Int.J.Curr.Microbiol.App.Sci. 8(03): 1740-1745. doi: https://doi.org/10.20546/ijcmas.2019.803.203 